\title{
Catalysis, Electrocatalysis and Electrochemical Promotion of the Steam Reforming of Methane over Ni Film and Ni-YSZ Cermet Anodes
}

\author{
I.V. Yentekakis, Y. Jiang, S. Neophytides, S. Bebelis and C.G. Vayenas \\ Department of Chemical Engineering \\ University of Patras, GR-26500 Patras, Greece
}

\begin{abstract}
The kinetics of the steam reforming reaction of $\mathrm{CH}_{4}$ were investigated at temperatures 750 to $950^{\circ} \mathrm{C}$ under both open-circuit and closed-circuit conditions on Ni-YSZ (Yttria Stabilized Zirconia) solid oxide fuel cell (SOFC) anodes and polycrystalline Ni film SOFC anodes of measured $\mathrm{Ni}$ surface area. It was found that the rate of methane reforming on the Ni surface exhibits a Langmuir-Hinshelwood type dependence on $\mathrm{P}_{\mathrm{CH}_{4}}$ and $\mathrm{P}_{\mathrm{H}_{2} \mathrm{O}}$ which results from competitive adsorption of carbonaceous species and oxygen or $\mathrm{OH}$. Consequently the rate is maximized for intermediate $\mathrm{P}_{\mathrm{CH}_{4}}$ to $\mathrm{P}_{\mathrm{H}_{2} \mathrm{O}}$ ratios. The reaction kinetics are affected significantly by cell current and potential under closed-circuit conditions. Over a rather wide range of operating conditions the observed rate changes are Faradaic, which implies negligible variation in the catalytic properties of the Ni surface with potential. At lower temperatures, however, and particularly under conditions of carbon deposition, the rates of $\mathrm{CO}, \mathrm{H}_{2}, \mathrm{CO}_{2}$ and, more importantly, carbon formation exhibit pronounced non-Faradaic (NEMCA), or electrochemical promotion, behaviour. Some non-Faradaic behaviour is also observed for higher $\mathrm{H}_{2} \mathrm{O}$ to $\mathrm{CH}_{4}$ ratios but in this case the effect of applied potential is reproducible but not readily reversible.
\end{abstract}

\section{Introduction}

One of the most attractive features of solid oxide fuel cells (SOFCs) is their ability to oxidize efficiently fuels such as $\mathrm{CH}_{4}$ or natural gas without the need of an external reformer. This is due to the catalytic action of the fuel-exposed Ni surface of the Ni-yttria stabilized zirconia (YSZ) cermet anode in the temperature range of SOFC operation $\left(850-1000^{\circ} \mathrm{C}\right)$. The Ni surface catalyzes the steam reforming reaction:

$$
\mathrm{CH}_{4}+\mathrm{H}_{2} \mathrm{O} \rightarrow \mathrm{CO}+3 \mathrm{H}_{2}
$$

and thus produces $\mathrm{H}_{2}$ and $\mathrm{CO}$ which can be readily oxidized electrochemically at the three-phase-boundaries $(\mathrm{tpb})$ Ni-YSZ-gas:

$$
\begin{aligned}
& \mathrm{H}_{2}+\mathrm{O}^{2-} \rightarrow \mathrm{H}_{2} \mathrm{O}+2 \mathrm{e}^{-} \\
& \mathrm{CO}+\mathrm{O}^{2-} \rightarrow \mathrm{CO}_{2}+2 \mathrm{e}^{-}
\end{aligned}
$$

The Ni surface also catalyzes very efficiently the watergas-shift reaction:

$$
\mathrm{H}_{2} \mathrm{O}+\mathrm{CO} \leftrightarrows \mathrm{CO}_{2}+\mathrm{H}_{2}
$$

thus further facilitating the SOFC operation by, generally, increasing the $\mathrm{H}_{2}$ to $\mathrm{CO}$ ratio at the tpb, thus eliminating a significant part of the activation overpotential associated with the anodic reaction (3).

The kinetics of the steam reforming reaction have been extensively studied on Ni surfaces due to the industrial importance of this reaction $[1,2,3]$. On the contrary much less information is available regarding the kinetics of the steam reforming reaction on Ni-YSZ cermets [4-7] and unfortunately, in some cases published data do not reflect true kinetics but the approach to thermodynamic equilibrium [7].

A detailed knowledge of the $\mathrm{CH}_{4}$ steam reforming kinetics on Ni-YSZ cermet anodes can be very important in optimizing the anode cermet design, although at the high 
operating temperatures of most SOFCs the kinetics of reactions (1) and (4) are fast and thus the approach to thermodynamic equilibrium is facile.

The reason that this information can be important in optimizing the anode cermet design is the following: Reaction (1) is quite endothermic $(\Delta \mathrm{H}=35 \mathrm{kcal} / \mathrm{mol})$ and thus, when occuring fast, can cause severe cooling of the anode near the SOFC anodic compartment entrance. Such a local cooling can have a severe adverse effect on SOFC performance and durability, but may, in principle, be avoided by judicious anode design, if the steam reforming kinetics are known.

Reactions (1) and (4) may be accompanied by carbon forming reactions, catalysed by the nickel anode, i.e. methane decomposition and $\mathrm{CO}$ disproportionation:

$$
\begin{aligned}
& \mathrm{CH}_{4} \leftrightarrows \mathrm{C}+2 \mathrm{H}_{2} \\
& 2 \mathrm{CO} \leftrightarrows \mathrm{CO}_{2}+\mathrm{C} \text { (Boudouard reaction) }
\end{aligned}
$$

Carbon deposition results in a rapid loss of reforming activity $[1,6]$ and in degradation of cell performance, thus knowledge of the kinetics and mechanism of coke formation is of great importance for optimizing cell operation. In general, the carbon-forming tendency decreases with increasing temperature and pressure, with increasing steam to carbon ratio and with increasing methane conversion $[1,8]$.

Under closed circuit conditions, i.e. during operation of the SOFC under load, pumping of $\mathrm{O}^{2-}$ to the anode is expected to alter the rate of formation of the products of the steam reforming reaction as well as the carbon deposition rate.

In the present study we have carried out kinetic measurements both under open and closed circuit conditions,

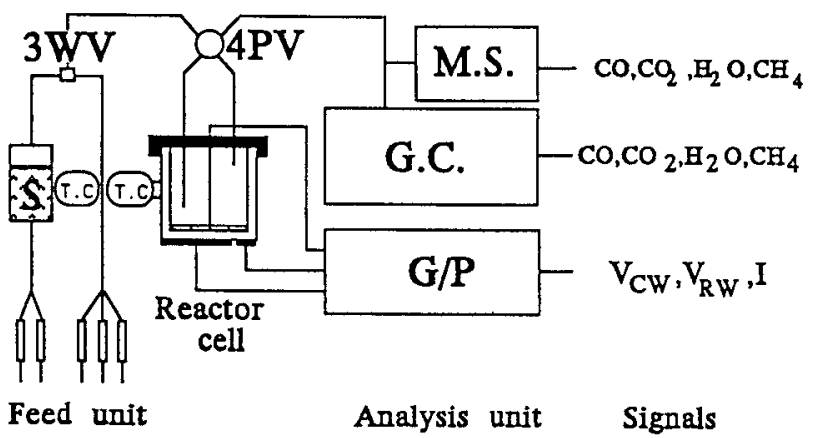

Fig. 1. Schematic of the apparatus; S: water saturator; $3 \mathrm{WV}$ : Three-way valve; 4PV:four port valve; M.S.: mass spectrometer; GC: gas chromatograph; G/P: galvanostat-potentiostat.

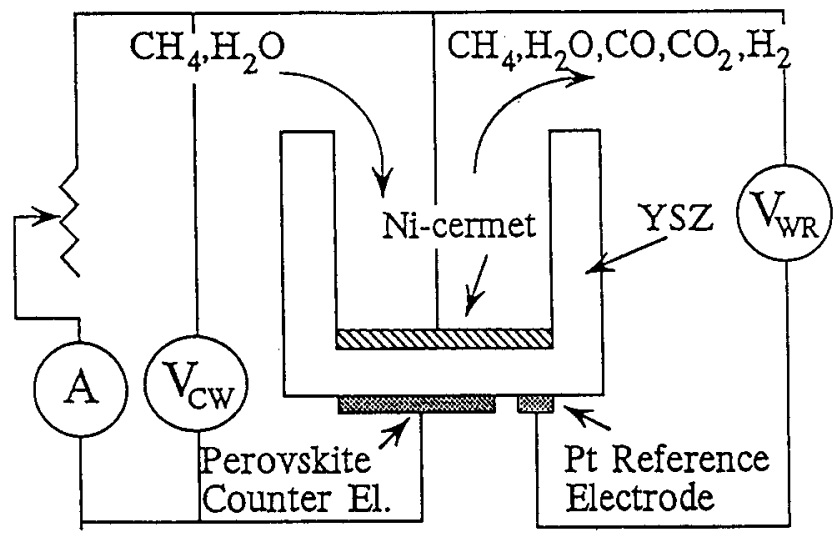

Fig. 2. Schematic of the fuel cell reactor

in order to investigate the effect of anode potential on the kinetic behaviour of the system and examine the Faradaic or non-Faradaic nature of the observed differences in catalytic rates.

\section{Experimental}

A schematic diagram of the experimental apparatus is shown in Fig.1. The feed $\mathrm{CH}_{4} / \mathrm{He}$ mixture was saturated with $\mathrm{H}_{2} \mathrm{O}$ by sparging through a thermostated water saturator. The fuel cell reactor inlet steam concentration was controlled by varying the saturator temperature. Reactants and products were analysed by on-line gas chromatography using a Shimadzu 14A gas chromatograph with a TC detector and a Shimadzu C-R5A integrator. A Porapak $\mathrm{N}$ column was used to separate $\mathrm{CO}, \mathrm{CH}_{4}, \mathrm{CO}_{2}$ and $\mathrm{H}_{2} \mathrm{O}$ and a molecular sieve $5 \mathrm{~A}$ column to separate $\mathrm{CO}$ and $\mathrm{CH}_{4}$.

In the series of experiments addressing the kinetics of coke formation a Carbosieve column was used to separate $\mathrm{H}_{2}, \mathrm{CO}, \mathrm{CH}_{4}$ and $\mathrm{CO}_{2}$ and a Porapak Q column to separate $\mathrm{H}_{2} \mathrm{O}$.

A Balzers QMG 311 mass spectrometer with a continuous gas sampling system and a Balzers 101 QDP data processor was also used for reactant and product analysis. This allowed for continuous monitoring of the effluent concentrations of $\mathrm{CO}, \mathrm{CO}_{2}, \mathrm{CH}_{4}, \mathrm{H}_{2}$ and $\mathrm{H}_{2} \mathrm{O}$.

The carbon formation rate was computed by the following equation:

$$
\mathbf{r}_{\mathrm{C}}=\frac{1}{2}\left[\mathrm{r}_{\mathrm{H}_{2}}-3 \mathrm{r}_{\mathrm{CO}}-4 \mathrm{r}_{\mathrm{CO}_{2}}\right]
$$

derived from the $\mathrm{C}, \mathrm{H}$ and $\mathrm{O}$ mass balances:

$$
\text { C: } r_{\mathrm{CH}_{4}}=\mathrm{rCO}^{+} \mathrm{rCO}_{2}+\mathrm{r}_{\mathrm{C}}
$$


Table 1.

\begin{tabular}{|c|c|c|c|c|c|}
\hline $\begin{array}{c}\text { Catalyst } \\
\#\end{array}$ & Type & $\begin{array}{l}\text { Surface Ni mols } \\
\qquad(\mathrm{N} / \mathrm{mol})\end{array}$ & $\begin{array}{l}\text { Exchange current } \\
\text { at } 800^{\circ} \mathrm{C} \mathrm{I}_{0} / \mathrm{mA}\end{array}$ & $\frac{2 \mathrm{Fr}_{\mathbf{o}}}{\mathbf{I}_{0}}$ & $\Lambda$ \\
\hline
\end{tabular}

$\begin{array}{llllll}\mathrm{C} 1 & \mathrm{Ni} / Y S Z \text { cermet } & 8.5 \cdot 10^{-8} & \sim 0.5 & 300 & - \\ \mathrm{C} 2 & \mathrm{Ni} / Y S Z \text { cermet } & 1.2 \cdot 10^{-7} & \sim 5 & 4 & \sim 1 \\ \mathrm{C} 3 & \mathrm{Ni} / \mathrm{YSZ} \text { cermet } & 6.3 \cdot 10^{-8} & \sim 2 & 300 & 25 \\ \mathrm{C} 4 & \mathrm{Ni} \text { film } & 3.0 \cdot 10^{-9} & \sim 0.2 & 40 & 15\end{array}$

$$
\begin{aligned}
& \mathrm{H}: 2 \mathrm{r}_{\mathrm{CH}_{4}}+\mathrm{r}_{\mathrm{H}_{2} \mathrm{O}}=\mathrm{r}_{\mathrm{H}_{2}} \\
& \mathrm{O}: \mathrm{r}_{\mathrm{H}_{2} \mathrm{O}}=\mathrm{rCO}+2 \mathrm{rCO}_{2}
\end{aligned}
$$

where $\mathrm{r}_{\mathrm{CH}_{4}}, \mathrm{r}_{\mathrm{H}_{2} \mathrm{O}}$ are the rates of consumption of $\mathrm{CH}_{4}$ and $\mathrm{H}_{2} \mathrm{O}$ and $\mathrm{rCO}_{\mathrm{C}} \mathrm{rCO}_{2}, \mathrm{r}_{\mathrm{H}}$ are the rates of formation of $\mathrm{CO}, \mathrm{CO}_{2}$ and $\mathrm{H}_{2}$, respectively, all expressed in mol/s.

All lines and valves were heated to $150^{\circ} \mathrm{C}$ to prevent condensation of $\mathrm{H}_{2} \mathrm{O}$. Reactants were certified standard of $\mathrm{CH}_{4}$ in $\mathrm{He}$ and ultrapure $99.999 \% \mathrm{He}$ (L' Air Liquide).

The atmospheric pressure $8 \mathrm{~mol} \% \mathrm{Y}_{2} \mathrm{O}_{3}$-stabilized $\mathrm{ZrO}_{2}$ continuous flow SOFC (Fig. 2), has a volume of $30 \mathrm{~cm}^{3}$ and has been described in detail previously (4-6). Within the flowrate range used in this investigation, i.e. typically $150-300 \mathrm{~cm}^{3} \mathrm{STP} / \mathrm{min}$, the anodic compartment has been shown to behave like a CSTR (Continuous Stirred Tank Reactor) by measuring the residence time distribution with an $\mathbb{R}$ analyzer [4].

Two types of Ni anodes were used in this investigation (Table 1). One type was a porous Ni film prepared by applying a thin coating of NiO paste on the YSZ surface (catalyst labeled $\mathrm{C} 4$, Table 1). The $\mathrm{NiO}$ paste was prepared by thoroughly admixing butyl acetate containing 5 wt\% poly-vinyl acetate binder and fine NiO powder prepared by decomposing nickel nitrate hexahydrate at $400^{\circ} \mathrm{C}$ for several hours. The deposited Ni paste was calcined in air at $450^{\circ} \mathrm{C}$ for $2 \mathrm{~h}$ and then at $900^{\circ} \mathrm{C}$ for $1 \mathrm{~h}$. The heating rate was $10^{\circ} \mathrm{C} / \mathrm{min}$.

The second type was Ni-YSZ cermet (Catalysts labeled $\mathrm{C} 1, \mathrm{C} 2, \mathrm{C} 3$ in Table 1), prepared as described elsewhere [5]. The porous Ni-YSZ anode $\left(-2 \mathrm{~cm}^{2}\right)$ was deposited on the inner side of the bottom of the YSZ tube while the $\mathrm{La}_{0.75} \mathrm{Sr}_{0.25} \mathrm{MnO}_{3}$ perovskite cathode $\left(\sim 1 \mathrm{~cm}^{2}\right)$, prepared via the metallo-organic decomposition method
(MOD) at $1200^{\circ} \mathrm{C}$, together with a small $\left(0.1 \mathrm{~cm}^{2}\right) \mathrm{Pt}$ reference electrode were deposited on the outer side on the YSZ and were exposed to ambient air. A porous Pt cathode was used in the experiments addressing the kinetics of carbon deposition.

The four catalyst electrode films used in the course of the investigation (Table 1) gave qualitatively similar open-circuit kinetic results. The total mass of the catalyst electrode $\mathrm{C} 1$ was $9.5 \mathrm{mg}$, while the true surface area of the Ni surface was $33 \mathrm{~cm}^{2}$ corresponding to $\mathrm{N}=8.5 \cdot 10^{-8}$ surface $\mathrm{Ni}$ mol as measured via $\mathrm{H}_{2}$ chemisorption in an Accusorb 2100 E Micromeritics chemisorption apparatus, which was also used to measure the Ni surface area of the catalyst electrode $\mathrm{C} 3$.

These values have been used to convert observed reaction rates $(\mathrm{mol} / \mathrm{s})$ into turnover frequencies (TOF) $\left(\mathrm{s}^{-1}\right)$, i.e. molecules reacting per surface $\mathrm{Ni}$ atom per $\mathrm{s}$. The surface areas of the other two catalyst electrodes (C2 and C4) were computed by comparing the rate of $\mathrm{CH}_{4}$ reforming under standard conditions $\left(\mathrm{P}_{\mathrm{H}_{2} \mathrm{O}} \approx 7 \mathrm{kPa}, \mathrm{P}_{\mathrm{CH}_{4}} \approx 9\right.$ $\mathrm{kPa}, \mathrm{T} \approx 850^{\circ} \mathrm{C}$ ).

An Amel 553 galvanostat-potentiostat was used both to apply and measure cell and anode potential as well as current flow through the cell.

\section{Results}

3.1. Steam Reforming Kinetics under Open-Circuit Conditions. In all kinetic experiments the total conversion (utilization) of $\mathrm{CH}_{4}$ was kept below $30 \%$ to ensure that true kinetics are observed which are not obscured by thermodynamic limitations. Figures 3 and 4 show typical results of the dependence of the rate of $\mathrm{CH}_{4}$ consumption $\mathrm{r}_{\mathrm{CH}_{4}}$ on the partial pressure of $\mathrm{H}_{2} \mathrm{O}, \mathrm{P}_{\mathrm{H}_{2} \mathrm{O}}$, and methane, $\mathrm{PCH}_{4}$. Note that the rate $\mathrm{rCH}_{4}$ is also expressed as a 


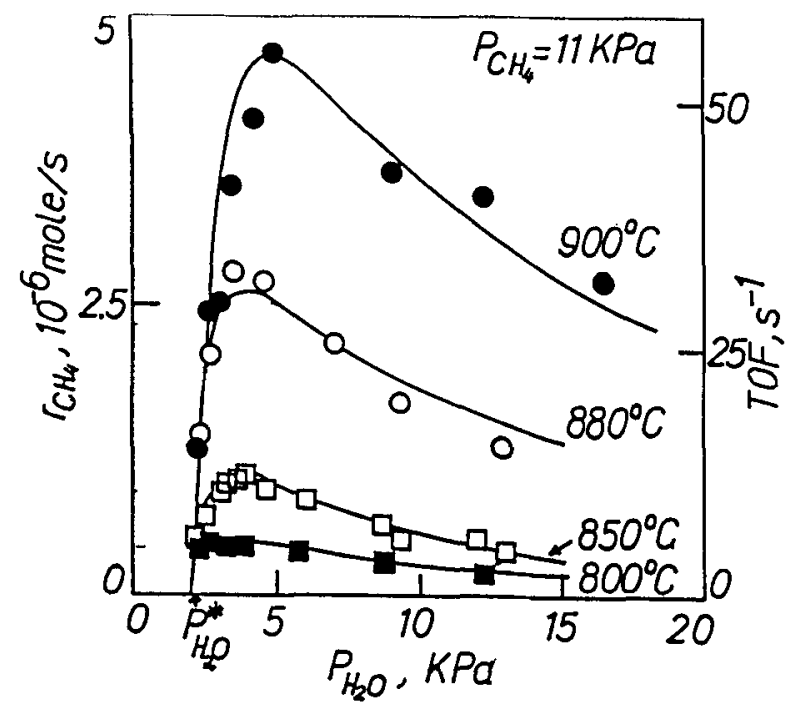

Fig. 3. Open-circuit effect of $\mathrm{P}_{\mathrm{H}_{2} \mathrm{O}}$ and temperature at fixed $\mathrm{P}_{\mathrm{CH}_{4}}$ on the total rate of $\mathrm{CH}_{4}$ consumption and on the corresponding turnover frequency; Catalyst electrode $\mathrm{C} 1$.

turnover frequency (TOF, $\mathrm{s}^{-1}$ ), i.e. molecules of $\mathrm{CH}_{4} \mathrm{re}-$ acting per surface Ni atom per sec, by using the measured Ni surface area.

The kinetics depicted on Fig. 3 have been obtained at constant $\mathrm{P}_{\mathrm{CH}_{4}}=11 \mathrm{kPa}$. Typically $90-95 \%$ of the converted $\mathrm{CH}_{4}$ appears as $\mathrm{CO}$, the rest as $\mathrm{CO}_{2}$ [9]. The first interesting feature of Fig. 3 is that there is a minimum $\mathrm{P}_{\mathrm{H}_{2} \mathrm{O}}$ pressure, subsequently denoted by $\mathrm{P}_{\mathrm{H}_{2} \mathrm{O}}^{*}$, below which $\mathrm{r}_{\mathrm{CH}_{4}}$ vanishes and extensive coking of the surface takes place. As discussed elsewhere [5] this low $\mathrm{P}_{\mathrm{H}_{2} \mathrm{O}}$ region is the region where $\mathrm{C}$ formation is thermodynamically favored via the Boudouard reaction:

$$
2 \mathrm{CO} \leftrightarrows \mathrm{CO}_{2}+\mathrm{C}
$$

For $\mathrm{P}_{\mathrm{H}_{2} \mathrm{O}}>\mathrm{P}_{\mathrm{H}_{2} \mathrm{O}}^{*}$ the rate of $\mathrm{CH}_{4}$ consumption increases linearly with $\mathrm{P}_{\mathrm{H}_{2} \mathrm{O}}-\mathrm{P}_{\mathrm{H}_{2} \mathrm{O}}^{*}$ (Fig. 3) until a maximum is reached. The maximum location shifts gradually to the right with increasing temperature, i.e. from $\approx 0.25$ at $800^{\circ} \mathrm{C}$ to $\approx 0.5$ at $900^{\circ} \mathrm{C}$. By further increasing $\mathrm{P}_{\mathrm{H}_{2} \mathrm{O}}$, the rate starts to decrease, i.e. the rate of $\mathrm{CH}_{4}$ consumption starts to exhibit negative order kinetics with respect to $\mathrm{H}_{2} \mathrm{O}$. This behaviour strongly indicates competitive adsorption of $\mathrm{CH}_{4}$ (in the form of active $\mathrm{C}$ ) and $\mathrm{H}_{2} \mathrm{O}$ (in the form of $\mathrm{OH}$ ) on the Ni catalyst surface and can be modeled within the framework of classical LangmuirHinshelwood kinetics [5,9].

Similar behaviour is shown on Fig. 4 which depicts the effect of $\mathrm{P}_{\mathrm{CH}_{4}}$ on $\mathrm{r}_{\mathrm{CH}_{4}}$ at constant $\mathrm{P}_{\mathrm{H}_{2} \mathrm{O}}=7 \mathrm{kPa}$. Again the rate goes through a maximum which occurs at

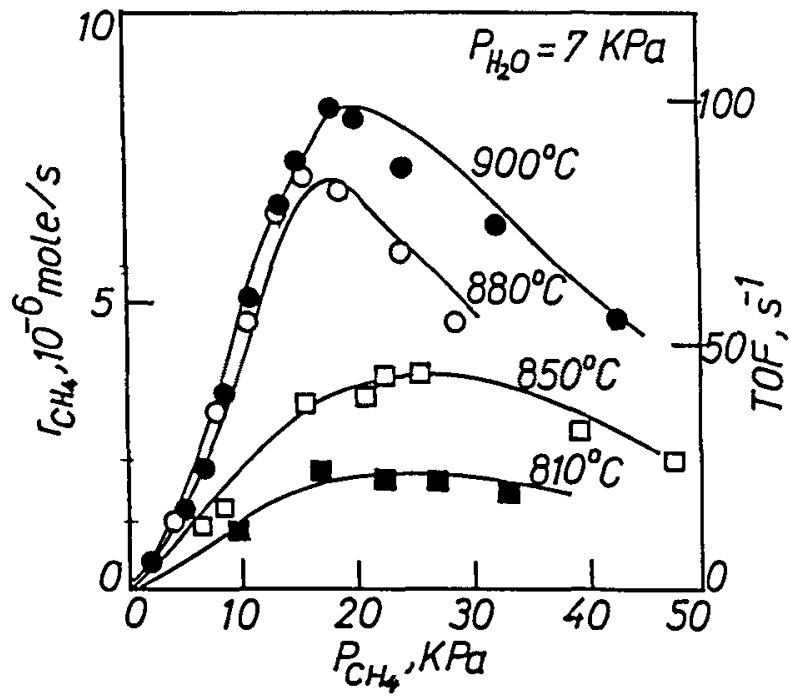

Fig. 4. Open-circuit effect of $\mathrm{PCH}_{4}$ and temperature at fixed $\mathrm{P}_{\mathrm{H}_{2} \mathrm{O}}$ on the total rate of $\mathrm{CH}_{4}$ consumption and on the corresponding turnover frequency; Catalyst electrode $\mathrm{Cl}$.

$\approx 0.25$ at lower temperatures and $\approx 0.5$ at $900^{\circ} \mathrm{C}$.

A detailed kinetic analysis and resulting approximate rate equations based on the data presented here and on a large volume of similar data not shown here due to space limitations, will be given elsewhere [9]. In general it was found that under most conditions the water-gas-shift reaction (4) is at or near equilibrium. One complicating factor in the present kinetic study was the appearance of rate hysteresis or "memory" effects due to formation of different amounts of coke on the catalyst surface. These memory effects were more pronounced at lower temperatures and become apparent by a careful comparison of the lower temperature data shown on Figs 3 and 4. Stated differently, for any fixed $\mathrm{T}, \mathrm{P}_{\mathrm{H}_{2} \mathrm{O}}, \mathrm{P}_{\mathrm{CH}_{4}}, \mathrm{P}_{\mathrm{CO}}$ and $\mathrm{P}_{\mathrm{CO}_{2}}$ the reaction rate can also depend on the catalyst previous history, i.e. on the amount of $\mathrm{C}$ originally present on the Ni surface.

The most important conclusion which can be drawn from Figs. 3 and 4 is that there exists an optimum temperature-dependent $\mathrm{P}_{\mathrm{H}_{2}} \mathrm{O} / \mathrm{P}_{\mathrm{CH}_{4}}$ ratio for $\mathrm{r}_{\mathrm{CH}_{4}}$ maximization and also for SOFC power production, as discussed elsewhere [5]. Too little $\mathrm{H}_{2} \mathrm{O}\left(\left(\mathrm{P}_{\mathrm{H}_{2} \mathrm{O}} / \mathrm{P}_{\mathrm{CH}_{4}}<0.15\right)\right.$ leads to excessive coke formation, but too much $\mathrm{H}_{2} \mathrm{O}\left(\mathrm{P}_{\mathrm{H}_{2} \mathrm{O}} \mathrm{O}\right.$ $\left.\mathrm{P}_{\mathrm{CH}_{4}}>0.5\right)$ also has an adverse effect on the open-circuit $\mathrm{CH}_{4}$ steam reforming rate.

\subsection{Steam Reforming Kinetics under Closed Circuit} Conditions - Faradaic Behaviour. Figure 5, obtained with the Ni cermet $\mathrm{C} 2$ (Table 1) shows the effect of varying steam partial pressure on the rate of $\mathrm{CO}$ production (which corresponds to typically $90-95 \%$ of the total 


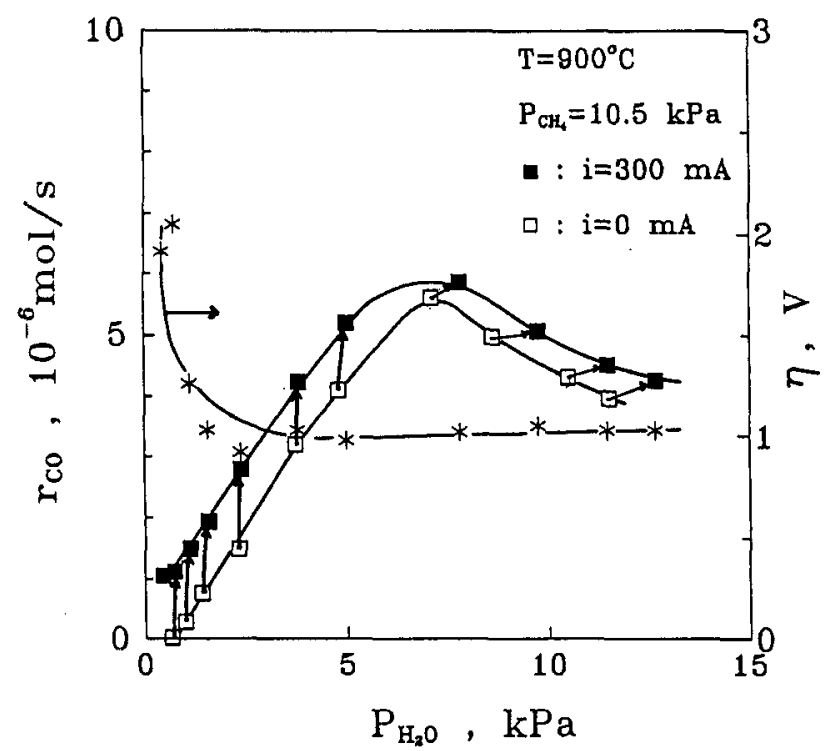

Fig. 5. Effect of $\mathrm{P}_{\mathrm{H}_{2} \mathrm{O}}$ on the rate of $\mathrm{CO}$ formation under open $(I=0)$ and closed $(I=300 \mathrm{~mA})$ circuit conditions and on anode overpotential. Total flowrate $155 \mathrm{csSTP} / \mathrm{min}$; Catalyst electrode C2; Arrows connect points obtained at the same inlet partial pressure of $\mathrm{H}_{2} \mathrm{O}$.

reforming rate) at $900^{\circ} \mathrm{C}$ both under open circuit conditions and under fuel cell operation, i.e. when a current of $300 \mathrm{~mA}$ flows through the cell. The overpotential $\eta$, also shown in Fig. 5 is defined as the deviation of the catalyst potential $V_{W R}$, with respect to the reference electrode, from its open-circuit $(\mathrm{I}=0)$ value.

The filled symbols, corresponding to fuel cell operation, represent the sum of the catalytic and electrocatalytic rate of $\mathrm{CO}$ production. As shown by the arrows connecting the corresponding points under open and closed circuit conditions, at high methane to steam ratios the predominant electrocatalytic reaction is methane partial oxidation to $\mathrm{CO}$ and $\mathrm{H}_{2}$ (synthesis gas):

$$
\mathrm{CH}_{4}+\mathrm{O}^{2-} \rightarrow \mathrm{CO}+2 \mathrm{H}_{2}+2 \mathrm{e}^{-}
$$

while for low methane to steam ratios there is little extra production of $\mathrm{CO}$ and a near-Faradaic increase in the rate of $\mathrm{H}_{2} \mathrm{O}$ production:

$$
\mathrm{CH}_{4}+4 \mathrm{O}^{2-} \rightarrow \mathrm{CO}_{2}+2 \mathrm{H}_{2} \mathrm{O}+8 \mathrm{e}^{-}
$$

The conclusion drawn from Fig. 5 is that the CO production rate is enhanced under fuel cell operation conditions and that the methane to water ratio determines the extent of each particular electrocatalytic reaction (11) or (12) taking place.

Furthermore it appears that during fuel cell operation

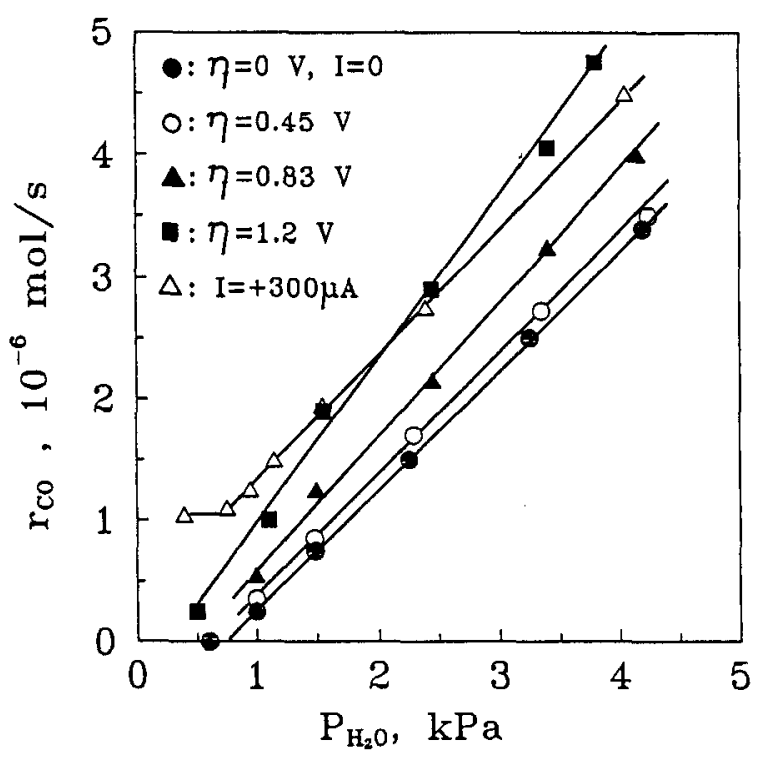

Fig. 6. Effect of $\mathrm{P}_{\mathrm{H}_{2} \mathrm{O}}$ on the rate of $\mathrm{CO}$ formation at various fixed overpotentials and currents; conditions as in Fig. 5.

the critical steam partial pressure necessary to avoid coke formation shifts to lower values.

The observed rate changes in this case (Fig. 5) are purely Faradaic, i.e. they correspond exactly to the rate of oxygen ion transfer to the Ni-YSZ cermet anode according to Faraday's law.

The faradaic rate changes shown in Fig. 5 imply that under these conditions altering anode potential determines solely the rate of the electrocatalytic reactions taking place at the three phase boundaries and does not affect the catalytic properties of the Ni-YSZ cermet anode. This is not surprising in view of the fact that the papameter $2 \mathrm{Fr}_{\mathrm{o}} / \mathrm{I}_{0}$ which provides a good qualitative measure of the Faradaic efficiency $\Lambda[4,10]$ is of the order of 4 for the catalyst film C2 (Table 1).

Figure 6 shows the effect of $\mathrm{P}_{\mathrm{H}_{2} \mathrm{O}}$ on the rate of $\mathrm{CO}$ formation at various fixed catalyst-electrode overpotentials and also for $\mathrm{I}=300 \mathrm{~mA}$. These data, obtained under the same conditions as those of Fig. 5, correspond to Faradaic increases in the total rate of $\mathrm{CH}_{4}$ consumption. 3.3. Non-Faradaic Behaviour. At lower operating temperatures $\left(\mathrm{T}<830^{\circ} \mathrm{C}\right)$ and under conditions of coke deposition, it was found that changing catalyst potential causes pronounced non-Faradaic variations in the rates of formation of $\mathrm{CO}, \mathrm{CO}_{2}, \mathrm{H}_{2}$ and $\mathrm{C}$, indicating significant potential-controlled variations in the catalytic activity of the Ni surface.

Typical examples are shown in Figs. 7 to 9 obtained with the catalyst electrode $\mathrm{C} 3$ (Table 1). Figure 7 shows rate changes measured between open-circuit operation 


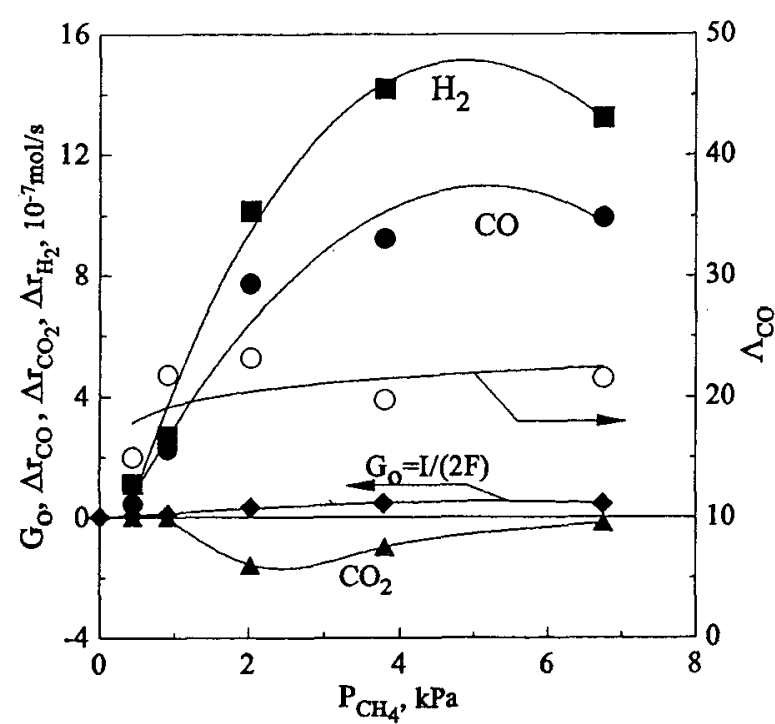

Fig. 7. Effect of $\mathrm{PCH}_{4}$ on the rate $\mathrm{G}_{\mathrm{O}}=\mathrm{I} / 2 \mathrm{~F}$ of $\mathrm{O}^{2-}$ transfer to the catalyst, on the change (vs open-circuit operation) in the rates of $\mathrm{CO}, \mathrm{CO}_{2}$ and $\mathrm{H}_{2}$ production and on the Faradaic efficiency $\Lambda \mathrm{CO}$ when the catalyst electrode potential is maintained at $\mathrm{V}_{\mathrm{WR}}=-0.6 \mathrm{~V} ; \mathrm{T}=826^{\circ} \mathrm{C} ; \mathrm{P}_{\mathrm{H}_{2} \mathrm{O}}=0.75 \mathrm{kPa}$; Catalyst C3.

$\left(I=0, V_{W R}^{o} \approx-1 V\right)$ and when the catalyst potential is maintained at $V_{W R}=-0.6 \mathrm{~V}$. The Figure thus shows the effect of $\mathrm{P}_{\mathrm{CH}_{4}}$ on the rate $\mathrm{I} / 2 \mathrm{~F}$ of $\mathrm{O}^{2-}$ transport to the catalyst-electrode and on the induced change in the rates of production of $\mathrm{CO}, \mathrm{H}_{2}$ and $\mathrm{CO}_{2}$ under conditions of spontaneous cell operation. It is obvious by comparing $\Delta \mathrm{r}_{\mathrm{CO}}$, $\Delta \mathrm{r}_{\mathrm{H}_{2}}$ and $\Delta \mathrm{r}_{\mathrm{CO}_{2}}$ with $\mathrm{I} / 2 \mathrm{~F}$ (Fig. 7) that the induced changes in the rates of $\mathrm{CO}, \mathrm{H}_{2}$ and $\mathrm{CO}_{2}$ production are strongly non-Faradaic. Thus the Figure also depicts the dependence on $\mathrm{P}_{\mathrm{CH}_{4}}$ of the Faradaic efficiency $\Lambda_{\mathrm{CO}}$ defined from:

$$
\Lambda_{\mathrm{CO}}=\frac{\Delta \mathrm{r}_{\mathrm{CO}}}{(\mathrm{I} / 2 \mathrm{~F})}
$$

As shown in Fig. 7, $\Lambda_{\mathrm{CO}}$ takes values between 15 and 30. The increase in the rate of $\mathrm{H}_{2}$ production is also strongly non-Faradaic, while, interestingly, $\mathrm{ICO}_{2} \mathrm{de}-$ creases and $-\Delta \mathbf{r O O}_{2}$ is up to a factor of 5 larger than $\mathrm{I} / 2 \mathrm{~F}$. Consequently, under the conditions of Fig.7, the Ni/YSZ cermet anode exhibits the effect of Electrochemical Promotion $[4,10]$ or non-Faradaic Electrochemical Modification of Catalytic Activity (NEMCA) $[4,10]$.

It is worth emphasizing that although the measured $\Lambda$ values in Fig. 7 are rather large $(-15)$ the corresponding $\rho$ $\left(=\mathrm{r} / \mathrm{r}_{\mathrm{o}}\right)$ values for the production of $\mathrm{H}_{2}, \mathrm{CO}$ and $\mathrm{CO}_{2}$ do not deviate significantly from unity, i.e. are typically in the range 0.9 to 2 . Regarding the carbon formation reac-

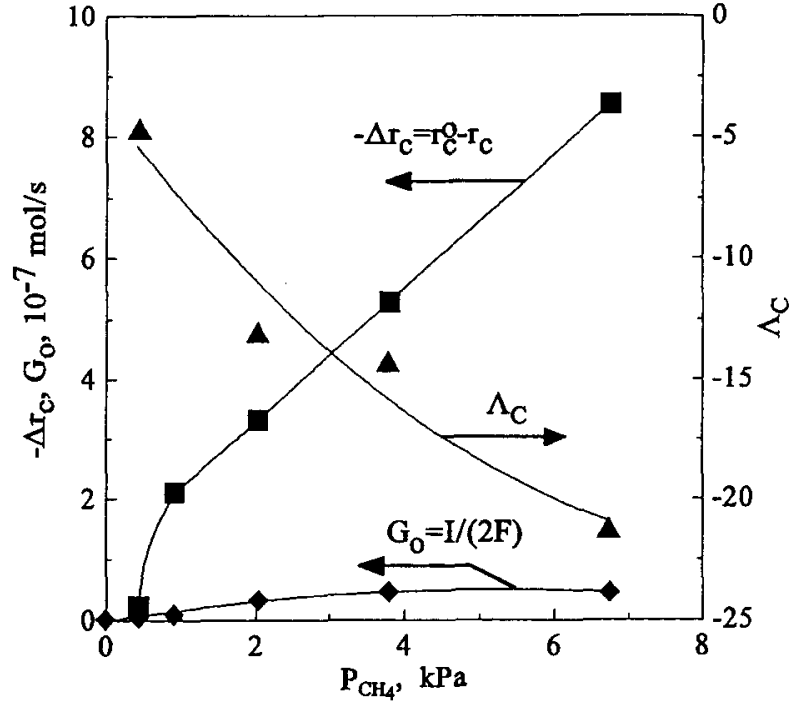

Fig. 8. Effect of $\mathrm{P}_{\mathrm{CH}_{4}}$ on the rate $\mathrm{G}_{\mathrm{O}}=\mathrm{I} / 2 \mathrm{~F}$ of $\mathrm{O}^{2-}$ transfer to the catalyst, on the change (vs open-circuit operation) in the rate ${ }_{C}$ of carbon formation and on the Faradaic efficiency $\Lambda_{C}$. Conditions as in Fig. 7.

tion rate, $\mathrm{r}_{\mathrm{C}}$, however, the situation is different and $\rho_{\mathrm{C}}\left(=\mathrm{r}_{\mathrm{O}} / \mathrm{r}_{\mathrm{C}, \mathrm{O}}\right)$ approaches zero over a certain $\mathrm{P}_{\mathrm{CH}_{4}}$ range, as shown below.

The rate $\mathrm{r}_{\mathbf{C}}$ of carbon formation is computed from Eq. (7). Figure 8, obtained via Eq. (7) from the data of Fig. 7 , shows the effect of $\mathrm{P}_{\mathrm{CH}_{4}}$ on the change in the rate $\mathrm{\Delta r}_{\mathrm{C}}$ of $\mathrm{C}$ formation and on the corresponding Faradaic efficiency $\Lambda_{C}$, defined from:

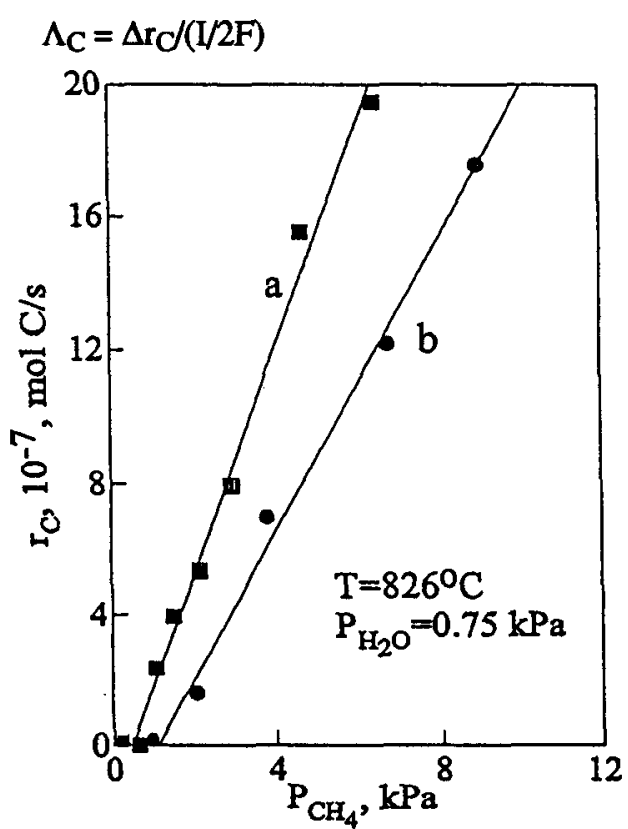

Fig. 9. Effect of $\mathrm{PCH}_{4}$ on the rate of $\mathrm{C}$ formation under opencircuit conditions (a) and for $V_{W R}=-0.6 \mathrm{~V}$ (b). Conditions as in Fig. 7. 
As shown in Fig. $8-\Delta \mathrm{r}_{\mathrm{C}}$ exceeds the rate $\mathrm{I} / 2 \mathrm{~F}$ of $\mathrm{O}^{2-}$ supply to the catalyst by up to a factor of 20 and thus $-\Lambda_{C}$ takes values up to 20 . The minus sign indicates that the carbon formation reaction is electrophilic, i.e., its rate is suppressed by positive current, or equivalently, increasing catalyst potential $[4,10]$.

Figure 9 shows the dependence of the rate of carbon formation, $\mathrm{r}_{\mathrm{C}}$, on $\mathrm{P}_{\mathrm{CH}_{4}}$. Interestingly $\mathrm{r}_{\mathbf{F}}$ increases linearly with $\mathrm{P}_{\mathrm{CH}_{4}}$ above a critical value $\mathrm{P}_{\mathrm{CH}_{4}}$. The lines labeled (a) and (b) in Fig. 9 correspond to open-circuit operation ( $\left.I=0, V_{W R} \approx-1 V\right)$ and $V_{W R}=-0.6 V$, respectively. Increasing catalyst potential decreases the apparent first-order rate constant for carbon formation and shifts $\mathrm{P}^{*} \mathrm{CH}_{4}$ to higher values. Between these two values of $\mathrm{P}_{\mathrm{CH}_{4}}$, it is $\rho_{\mathrm{C}}=0$, i.e. the rate of $\mathrm{C}$ formation is totally suppressed by increasing catalyst potential.

The NEMCA behaviour depicted in Figs. 7 to 9 is quite reversible, as in previous NEMCA studies $[4,10]$, and is observed for low, typically less than $0.25, \mathrm{P}_{\mathrm{H}_{2} \mathrm{O}} /$ $\mathrm{P}_{\mathrm{CH}_{4}}$ values, i.e. under conditions of carbon deposition.

We have also observed a second type of Non-Faradaic behaviour at high $(>0.5) \mathrm{P}_{\mathrm{H}_{2}} \mathrm{O} / \mathrm{P}_{\mathrm{CH}_{4}}$ ratios and a typical example is shown in Fig. 10. This figure shows the transient response of the exit stream $\mathrm{H}_{2} \mathrm{O}, \mathrm{CH}_{4}$ and $\mathrm{CO}$ mole fractions and cell current upon imposing a constant potential $V_{W R}=1 \mathrm{~V}$ between the catalyst and reference electrodes at $800^{\circ} \mathrm{C}$ and a feed $\mathrm{H}_{2} \mathrm{O}$ to $\mathrm{CH}_{4}$ ratio of 0.6.

As shown in the potentiostatic transient of Fig. 10 the cell current exhibits a pronounced maximum before stabilizing to a value of $20 \mathrm{~mA}$. The steam and $\mathrm{CH}_{4}$ conversions increase significantly with a concomitant 57 fold $(5700 \%)$ increase in the rate of $\mathrm{CO}$ production. This rate increase $\Delta r_{C O}=1.45 \cdot 10^{-6} \mathrm{~mol} \mathrm{CO} / \mathrm{s}$ is 15 times larger than the steady state rate $\mathrm{I} / 2 \mathrm{~F}$ of $\mathrm{O}^{2-}$ supply to the catalyst. Consequently under these conditions the steam reforming reaction:

$$
\mathrm{CH}_{4}+\mathrm{H}_{2} \mathrm{O} \rightarrow \mathrm{CO}+3 \mathrm{H}_{2}
$$

exhibits the NEMCA effect with $\Lambda=15$ and $\rho=57$, i.e., the catalytic properties of the Ni-YSZ anode cermet are affected significantly by the applied current and potential. It was noticed, however, that although the transient behaviour depicted in Fig. 10 is quite reproducible, the system lacks reversibility, i.e. current interruption does not restore the initial state, even after many $(>60)$ minutes of operation. It is thus very likely that the observed pronounced non-Faradaic behaviour of Fig. 10 is due to the clean-off effect of $\mathrm{O}^{2-}$ on carbon previously deposited on

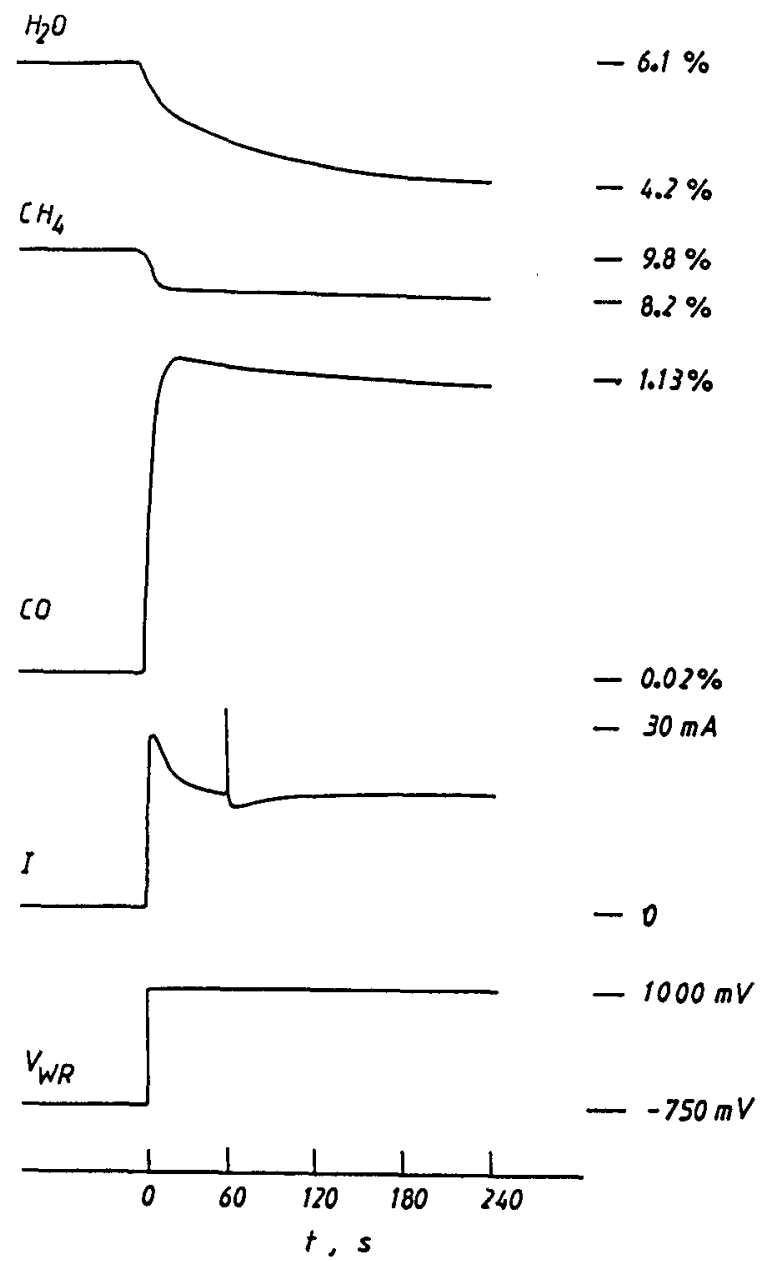

Fig. 10. Potentiostatic $\left(V_{W R}=+1 V\right)$ transient. Effect of applied potential on cell current $I$ and on the mole fractions of $\mathrm{H}_{2} \mathrm{O}, \mathrm{CH}_{4}$ and $\mathrm{CO}$ in the cell reactor effluent; total flowrate $205 \mathrm{ccSTP} / \mathrm{min}$; Catalyst C4.

the $\mathrm{Ni}$ surface. This is also corroborated by the observed transient maximum in current and mole fraction of $\mathrm{CO}$ (Fig. 10).

Fig. 11 shows for the same catalyst film and under the same conditions the effect of $\mathrm{P}_{\mathrm{H}_{2} \mathrm{O}}$ on the rate of $\mathrm{CO}$ production under open circuit conditions and, when the anode potential is maintained at $1 \mathrm{~V}$ with respect to the reference electrode. For $\mathrm{P}_{\mathrm{H}_{2} \mathrm{O}} / \mathrm{P}_{\mathrm{CH}_{4}}$ above $\sim 0.5$ there is an abrupt fifty-fold $(-5000 \%)$ increase in the rate of $\mathrm{CO}$ production.

Figure 12 shows the effect of catalyst potential $V_{W R}$ on the rate of $\mathrm{CO}$ formation at fixed $\mathrm{P}_{\mathrm{H}_{2} \mathrm{O}}$ and $\mathrm{P}_{\mathrm{CH}_{4}}$. Above a threshold $\mathrm{V}_{\mathrm{WR}}$ value of $\sim 0.4 \mathrm{~V}$ the rate increases abruptly by approximately $5000 \%$. As previously noted, however, the return from the high-rate state to the low-rate state of Figures 11 and 12 is very slow and is probably controlled by the rate of carbon deposition on the Ni surface. 


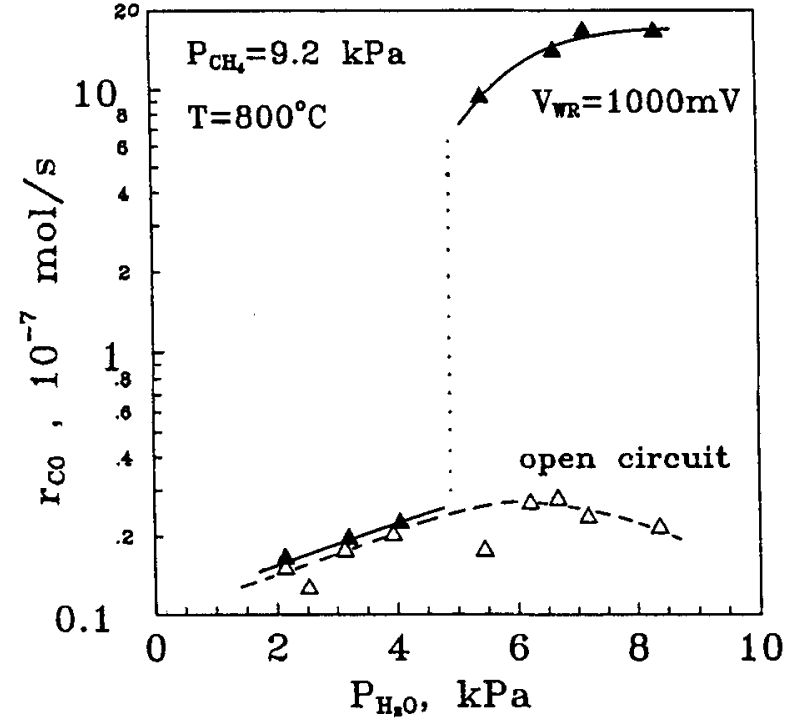

Fig. 11. Effect of $\mathrm{P}_{\mathrm{H}_{2} \mathrm{O}}$ on the rate of $\mathrm{CO}$ formation under open-circuit conditions and for $V_{W R}=+1 V$; Catalyst $C 4$

\section{Conclusions}

The main conclusions of the present work can be summarized as follows:

1. There is a minimum $\mathbf{P}_{\mathrm{H}_{2} \mathrm{O}}$ value necessary to avoid excessive coke formation on the Ni cermet anode. This value is close to the one computable from thermodynamics.

2. There is an optimal $\mathrm{P}_{\mathrm{H}_{2} \mathrm{O}} / \mathrm{P}_{\mathrm{CH}_{4}}$ ratio $(0.25-0.5)$ for maximization of the reforming rate under open-circuit conditions. This is due to the competitive adsorption of $\mathrm{C}$ and $\mathrm{OH}$ on the $\mathrm{Ni}$ catalyst surface.

3. The kinetics of the steam reforming reaction and of carbon deposition on Ni-YSZ cermet anodes can be

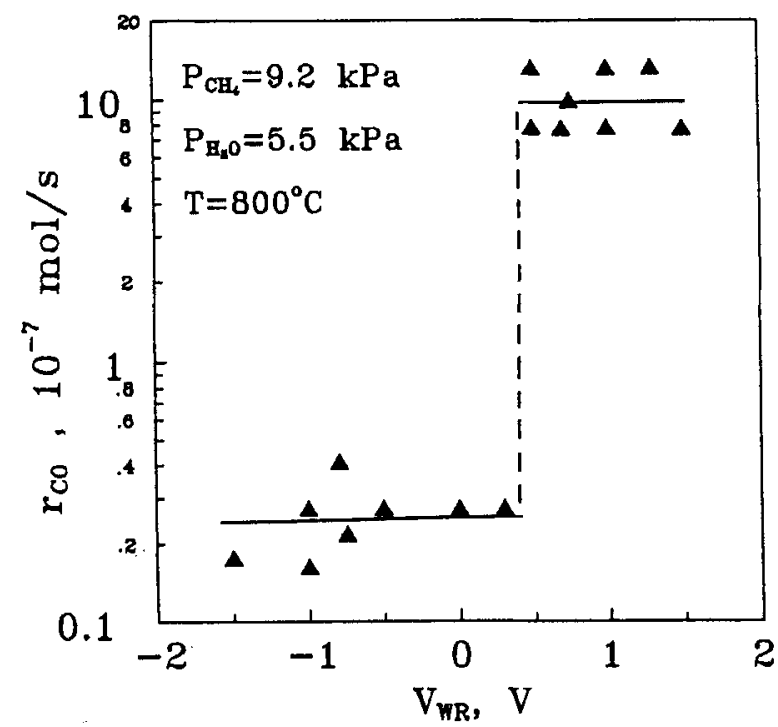

Fig. 12. Effect of $\mathrm{V}_{\mathrm{WR}}$ on the rate of $\mathrm{CO}$ formation; Catalyst C4 affected significantly by the anode potential. At low operating temperatures, positive overpotentials can modify the catalytic activity of the Ni-YSZ cermet anode so that the reforming rate is significantly enhanced and the carbon deposition is hindered. This demonstration of the effect of Non-Faradaic Electrochemical Modification of Catalytic Activity (NEMCA) may be of practical importance for the operation of SOFCs at temperatures below $850^{\circ} \mathrm{C}$. The system is, however, kinetically complex and in view of the observed hysteresis effects, a more systematic investigation is necessary.

\section{Acknowledgement}

Financial support by the EEC Non-Nuclear Energy and JOULE Programmes is gratefully acknowledged.

\section{References}

[1] J.R. Rostrup-Nielsen in "Catalysis-Science and Technology" (J.R. Anderson and M. Boudart, Eds.), V5, Springer-Verlag, Berlin (1983).

[2] J.R. Rostrup-Nielsen, "Steam Reforming Catalysts", Davisk Technical Press Inc, Kopenhagen (1975)

[3] J.R. Rostrup-Nielsen and I. Alstrup, "Catalysis 1987", Elsevier, Amsterdam (1988), p. 725.

[4] C.G. Vayenas, S. Bebelis, I.V. Yentekakis and H.G. Lintz, Catal. Today 11(3), 303-442 (1992).

[5] I.V. Yentekakis, S.G. Neophytides, A.C. Kaloyannis and C.G. Vayenas, Proc. 3rd Int. Symp. on SOFCs, (S.C. Singhal and H. Iwahara, Eds.), Proc. Vol. 93-94, pp. 904-912, The Electrochemical Soc., Inc., (1993).

[6] S. Bebelis, S. Neophytides \& C.G. Vayenas, Proc. 1st European SOFC Forum (U. Bossel, Ed.), Vol. 1, pp. 197-206, Lucerne, Switzerland (1994).

[7] A.L. Lee, R.F. Zabransky and W.J. Huber, Ind. Eng. Chem. Res. 29, 766 (1990).

[8] C.H. Bartholomew, Cat. Rev.-Sci. Eng. 24(1) 67 (1982).

[9] S. Bebelis, Y. Jiang, S. Neophytides, I.V. Yentekakis \& C.G. Vayenas, in preparation.

[10] C.G. Vayenas, S. Bebelis and S. Ladas, Nature 343,625 (1990).

Paper presented at the 2nd Euroconference on Solid State Ionics, Funchal, Madeira, Portugal, Sept. 10-16, 1995

Manuscript received Nov. 14, 1995 